\title{
Abol-Hasan Kharaqhani, Vraje Abramian. The Soul and a Loaf of Bread: The Teachings of Sheikh Abol- Hasan of Kharaqan
}

Ève Feuillebois-Piérunek

\section{(2) OpenEdition}

1 Journals

Édition électronique

URL : http://journals.openedition.org/abstractairanica/40323

DOI : 10.4000/abstractairanica.40323

ISSN : 1961-960X

Éditeur :

CNRS (UMR 7528 Mondes iraniens et indiens), Éditions de l'IFRI

Édition imprimée

Date de publication : 1 décembre 2013

ISSN : 0240-8910

Référence électronique

Ėve Feuillebois-Piérunek, «Abol-Hasan Kharaqhani, Vraje Abramian. The Soul and a Loaf of Bread: The Teachings of Sheikh Abol-Hasan of Kharaqan », Abstracta Iranica [En ligne], Volume 32-33 | 2013, document 378, mis en ligne le 01 juillet 2016, consulté le 28 septembre 2020. URL : http:// journals.openedition.org/abstractairanica/40323; DOI : https://doi.org/10.4000/abstractairanica 40323

Ce document a été généré automatiquement le 28 septembre 2020.

Tous droits réservés 


\title{
Abol-Hasan Kharaqhani, Vraje Abramian. The Soul and a Loaf of Bread: The Teachings of Sheikh Abol-Hasan of Kharaqan
}

\author{
Ève Feuillebois-Piérunek
}

\section{RÉFÉRENCE}

Abol-Hasan Kharaqhani, Vraje Abramian. The Soul and a Loaf of Bread: The Teachings of Sheikh Abol-Hasan of Kharaqan. Trad. Vraje Abramian, Prescott, Arizona, Hohm Press, 2010, 86 p.

1 Ce petit livre contient la traduction anglaise de deux cents courtes sentences attribuées à Abū al-Ḥasan Hुaraqānī (m. 1034) à partir de l'édition de ces dits dans Nevešte bar daryā de M. R. Šafīīi Kadkanī (Téhéran, SoHnan, 1988). Il n'a aucune prétention scientifique, aucun apparat critique. Destiné au grand public, il essaie uniquement de communiquer une « saveur » de cette littérature mystique des « Paroles » des maîtres

\section{AUTEURS}

ÈVE FEUILLEBOIS-PIÉRUNEK

Université Sorbonne Nouvelle-Paris 3, Mondes iranien et indien, Paris 